\title{
ЭКСПРЕССИЯ ГЕНА $\alpha$-АМИЛАЗЫ StAmy23 В ФОТОСИНТЕЗИРУЮЩИХ И НЕФОТОСИНТЕЗИРУЮЩИХ ТКАНЯХ РАСТЕНИЙ У СОРТОВ КАРТОФЕЛЯ Solanum tuberosum L.*
}

\author{
А.В. КУЛАКОВА ${ }^{1} \bowtie$, А.А. МЕЛЕШИН ${ }^{2}$, А.В. ЩЕННИКОВА ${ }^{1}$, Е.3. КОЧИЕВА ${ }^{1}$
}

Картофель (Solanum tuberosum L.) - четвертая по значимости сельскохозяйственная культура после зерновых. У растения картофеля почти в каждой ткани содержится крахмал, регуляция метаболизма и физиологическая роль которого зависят от типа ткани, стадии развития растения и внешних факторов. Гидролиз крахмала катализируется $\alpha$ - (АМY) и $\beta$ - (ВАМ) амилазами. Посредством деградации цитозольного фитогликогена амилаза StAmy23 регулирует холодовое осахаривание и состояние физиологического покоя клубней картофеля. Немногочисленные имеющиеся исследования StAmy23 сосредоточены на активности гена в клубнях картофеля, в том числе в ответ на холодовой стресс. В настоящей работе впервые определен паттерн экспрессии гена StAmy 23 в фотосинтезирующих и нефотосинтезирующих органах растений картофеля трех сортов, различающихся содержанием крахмала в клубнях, - Gala (среднеранний) и Saturna (среднепоздний) (сорта зарубежной селекции) и Барин (среднеспелый российский сорт). Структурно-филогенетический анализ выявил, что ближайшими гомологами StAmy23 являются $\alpha$-амилазы разных сортов картофеля и томата. Определение количества углеводов в свежесобранных клубнях исследуемых сортов выявило сходное высокое содержание крахмала у сортов Gala и Saturna, в клубнях сорта Барин этот показатель был почти в 2 раза ниже (6,3 против 11,34 мг/г ткани). Наибольшее количество редуцирующих сахаров в клубнях мы обнаружили у сорта Saturna; клубни сорта Gala содержали соответственно в 4,5 и в 24,5 раза меньше глюкозы/фруктозы, чем клубни сортов Барин и Saturna (0,016/0,000 против 0,056/0,016 и 0,217/0,175 мг/г ткани). Нами впервые определен профиль экспрессии StAmy23 не только в клубнях, стеблях и листьях, но и в других органах и тканях растения картофеля. Показан высокий уровень экспрессии гена в стеблях и ягодах. Уровень транскрипци StAmy23 в нефотосинтезирующих корнях и столонах либо соответствовал таковому в клубнях (Saturna), либо значительно превышал его (Барин и Gala). В стеблях наибольшую и наименышую активность транскрипции StAmy23 отмечали соответственно у сортов Gala и Saturna $(0,58$ и 0,13). Листья и кожура характеризовались сходным и сравнительно низким уровнем экспрессии StAmy23. Самый высокий уровень экспрессии гена StAmy23 в ягодах выявили у сорта Барин $(0,29)$, в корнях и клубнях у сорта Gala $(0,55$ и 0,17$)$ и в столонах у сортов Барин и Gala $(0,31$ и 0,33$)$. Между уровнем транскрипци $S t A m y 23$ и содержанием крахмала (но не содержанием редуцирующих сахаров) в клубнях наблюдалась явная положительная зависимость. Транскрипционная активность гена StAmy23 в фотосинтезирующих тканях растений картофеля предполагает участие кодируемой им $\alpha$-амилазы в гидролизе крахмала не только в запасающих, но и в вегетативных органах для поддержания физиологических процессов роста и ответа растений на стресс.

Ключевые слова: Solanum tuberosum, картофель, $\alpha$-амилаза, StAmy23, содержание крахмала, содержание редуцирующих сахаров, экспрессия гена.

Картофель (Solanum tuberosum L.) - четвертая по значимости культура после зерновых (риса, пшеницы и кукурузы) для обеспечения продовольственной безопасности и экономического развития в мире. Основные питательные свойства картофеля определяются прежде всего качеством и количеством белков, минеральных элементов и крахмала в клубнях.

Формирование запасающих органов растений зависит от импорта углеродных соединений из исходных фотосинтезирующих тканей для обеспечения субстратов для биосинтеза всех метаболитов, включая крахмал. После уборки урожая и в течение определенного периода хранения клубни картофеля находятся в состоянии физиологического покоя, нарушение которого отрицательно сказываются на потребительских свойствах и технологических характеристиках клубней $(1,2)$. Клубни хранят при низких температурах (ниже $+4^{\circ} \mathrm{C}$ ) для того, чтобы замедлить прорастание побегов, потерю влаги и патогенез. Такое хранение часто приводит к так

* Работа выполнена при поддержке ФНТП развития сельского хозяйства РФ на 2017-2025 годы (подпрограмма «Развитие селекции и семеноводства картофеля в Российской Федерации»). 
называемому холодовому осахариванию (cold induced sweetening; CIS), что проявляется в накоплении редуцирующих сахаров (глюкоза, фруктоза) и, как следствие, приводит к потемнению картофеля во время жарки с образованием акриламида $(3,4)$. Понимание механизмов регуляции покоя клубней и их ответа на абиотический стресс (например, пониженные температуры) очень важно как для семеноводства картофеля, так и для его последующей переработки.

Крахмал содержится не только в запасающих органах. Гранулы крахмала можно найти почти в каждой ткани растения на определенной стадии его жизненного цикла. Метаболизм крахмала универсален, а его регуляция и физиологическая роль варьируются в зависимости от ткани, стадии развития растения и внешних факторов (5-7). В фотосинтезирующих тканях крахмал подвержен быстрой деградации, которая происходит в ночное время, в стрессовых условиях или же во время старения $(7,8)$. Крахмал накапливается в пластидах: запасной - в амилопластах гетеротрофных органов, транзиентный - в хлоропластах фотосинтезирующих органов $(9,10)$.

Таким образом, крахмал может быть источником сахаров, когда необходим углерод, или служить своеобразным депо, когда сахара присутствуют в избытке, что позволяет оптимально использовать запасы углерода $(11,12)$. Разложение крахмала происходит гидролитически или фосфоролитически. В гидролитический путь вовлечены $\alpha$-амилазы (АМY, ЕС 3.2.1.1) и $\beta$-амилазы (BAM, ЕС 3.2.1.2) $(13,14)$.

AMY - это эндоамилолитический фермент, который специфически

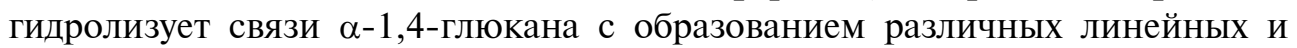
разветвленных мальтоолигосахаридов. Множественные гены $\alpha$-амилаз кодируют их различные изоформы, которые могут выполнять разные роли в зависимости от тканевой локализации и вида растений. Например, подавление $\alpha$-амилазы I-1 риса приводит к увеличению накопления крахмала в молодых листьях $(15,16)$. Напротив, у Arabidopsis все мутанты с одиночным, двойным и тройным нокаутом AtAMY демонстрируют нормальный распад крахмала $(17,18)$.

В геноме картофеля идентифицировано пять генов $A M Y$, активность продуктов которых специфична по отношению к различным субстратам и в разных клеточных структурах, например в хлоропластах и амилопластах $(4,19)$. Два из них - StAmy1 и StAmy 23 экспрессируются в клубнях, но только StAmy23 индуцируется пониженной температурой (20). Гомолог этого гена у яблони - ген $A m y 8$ также чувствителен к холоду; его экспрессия активируется в ягодах при $0,5^{\circ} \mathrm{C}(21)$. Амилаза StAmy23 локализуется в цитоплазме и регулирует холодовое осахаривание клубней посредством деградации цитозольного фитогликогена: замолкание StAmy23 приводит к повышенному содержанию крахмала и снижению количества редуцирующих сахаров в клубнях, хранящихся при пониженных положительных температурах (4). Кроме того, StAmy23 участвует в регуляции покоя клубней картофеля, и подавление экспрессии этого гена задерживает прорастание клубней, что сопровождается уменьшением количества редуцирующих сахаров в кожуре и сердцевинной ткани под почками клубней, а также небольшим изменением структуры фитогликогена и размера гранул крахмала (2). Таким образом, StAmy23 может стимулировать прорастание почек в клубнях, находящихся в состоянии физиологического покоя, обеспечивая поступление сахаров посредством гидролиза растворимого крахмала (2).

Интересно, что все (очень немногочисленные) исследования StAmy23 сосредоточены только на активности гена в клубнях картофеля, в том числе 
в ответ на холодовой стресс.

В настоящей работе впервые определен профиль экспрессии StAmy23 в различных органах и тканях растений картофеля. Показан высокий уровень экспрессии гена в стеблях и ягодах, а также в нефотосинтезирующих корнях и столонах, где уровень транскрипции StAmy23 либо соответствовал таковому в клубнях, либо значительно превышал его.

Целью работы было сравнение экспрессии гена StAmy23 в фотосинтезирующих и нефотосинтезирующих органах у трех сортов картофеля российской и зарубежной селекции, различающихся содержанием крахмала в клубнях.

Методика. Сравнительный биоинформатический структурный анализ депонированных в NCBI Nucleotide collection нуклеотидных последовательностей мРНК, кодирующих белки-гомологи StAmy23 у разных видов растений, и соответствующих аминокислотных последовательностей StAmy23 проводили с использованием программного обеспечения NCBI-BLAST (http://blast.ncbi.nlm.nih.gov/Blast.cgi). Филогению StAmy23 оценивали методом Fast Minimum Evolution (Grishin distance matrix, https://www.ncbi.nlm.nih.gov/blast/treeview/). На основе выполненного сравнительного структурного анализа найденных в NCBI кодирующих и полных последовательностей генов $\alpha$-амилаз, гомологичных StAmy23, разрабатывали кДНК-специфичные праймеры для проведения количественной ПЦР в реальном времени (РВ-ПЦР). Прямой и обратный праймеры подбирали таким образом, чтобы между ними находился, как минимум, один интрон.

Для анализа профиля экспрессии гена StAmy23 в различных тканях растений картофеля, а также определения содержания крахмала и редуцирующих сахаров (глюкоза и фруктоза) в клубнях использовали сорт картофеля (Solanum tuberosum L.) Барин (среднеспелый) российской селекции и сорта Gala (среднеранний) и Saturna (среднепоздний) зарубежной селекции, различающиеся, по данным оригинаторов (https://reestr.gossortrf.ru/), содержанием крахмала в клубнях: Барин - среднее $(13,4-14,6$ \%), Saturna высокое $(16,5-21,4 \%)$, Gala - низкое (10,2-13,2 \%). Все три сорта (предоставлены ВНИИКХ им. А.Г. Лорха, Московская обл.) относятся к столовым и не используются для промышленного изготовления чипсов. Растения выращивали в 2020 году в полевых условиях (ВНИИКХ им. А.Г. Лорха, Московская обл.). В сентябре 2020 года собирали по два растения каждого сорта, отделяли клубни, кожуру клубней, мякоть клубней, корни, столоны, стебли, листья и ягоды для последующего анализа экспрессии гена амилазы StAmy23, клубни (целиком с кожурой и мякотью) также использовали для определения содержания крахмала и редуцирующих сахаров.

Для выделения суммарной РНК использовали по 50-100 мг ткани клубней, кожуры клубней, мякоти клубней, корней, столонов, стеблей, листьев и ягод. Суммарную РНК выделяли с помощью набора RNeasy Plant Mini Kit («Qiagen», Германия) согласно протоколу производителя. Полученные препараты дополнительно очищали от примесей ДНК (набор RNase free DNasy set; «Qiagen», Германия) в соответствии с рекомендациями производителя. Синтез кДНК выполняли с использованием набора GoScript ${ }^{\mathrm{Tm}}$ Reverse Transcription System («Promega», США) по прилагаемому протоколу. Концентрацию РНК и кДНК определяли на флуориметре Qubit 4 («Thermo Fisher Scientific», США) с помощью соответствующих реактивов (Qubit RNA HS Assay Kit и Qubit DS DNA HS Assay Kit, «Invitrogen», США). Дополнительно качество РНК проверяли методом электрофореза в 1,5 \% агарозном геле с использованием стандарта длин FastRuler Middle Range DNA Ladder («Thermo Fisher Scientific», США). 
Анализ экспрессии гена StAmy23 в корнях, столонах, клубнях, кожуре клубней, мякоти клубней, стеблях, листьях и ягодах растений картофеля у всех трех сортов - Saturna, Gala и Барин проводили методом PBПЦР (RT-qPCR). Относительный уровень экспрессии StAmy23 определяли в сравнении с транскрипцией референсных генов efl (праймеры 5'-ATTGGAAACGGATATGCTCCA-3' и 5' -TCCTTACCTGAACGCCTGTCA-3') и $\sec 3$ (5'-GCTTGCACACGCCATATCAAT-3' и 5' -TGGATTTTACCACCTTCCGCA-3') (22, 23). Для РВ-ПЦР использовали 100 нг кДНК-матрицы, набор «Реакционная смесь для проведения РВ-ПЦР в присутствии SYBR GreenI и ROX» (OOO «Синтол», Россия) согласно рекомендациям производителя и термоциклер CFX96 Real-Time PCR Detection System («Bio-Rad Laboratories», США). Реакции проводили в двух биологических и трех технических повторах в следующих условиях: 5 мин при $95{ }^{\circ} \mathrm{C}$; 15 с при $95{ }^{\circ} \mathrm{C}$, 50 с при $62{ }^{\circ} \mathrm{C}$ (40 циклов).

Для количественного определения общего крахмала материал клубней (включая мякоть и кожуру) (500 мг) гомогенизировали в 4,5 мл раствора, содержащего диметилсульфоксид (DMSO, 33 \%, v/v) и соляную кислоту $(0,44 \mathrm{M})$, инкубировали при $60{ }^{\circ} \mathrm{C}$ в течение 30 мин на водяной бане, охлаждали до $25^{\circ} \mathrm{C}$ и разбавляли водой $(\mathrm{mQ})$ в соотношении 1:5; pH доводили до 4,5 с помощью 5 М гидроксида натрия. Суспензию фильтровали через Miracloth («Merck», США); 100 мкл фильтрата использовали для измерения содержания крахмала с помощью ферментного теста Starch («Boehringer Mannheim/R-Biopharm AG», Швейцария) согласно протоколу производителя (спектрофотометр Eppendorf BioSpectrometer ${ }^{\circledR}$ basic, «Eppendorf», Германия; $\lambda=340$ нм).

Для оценки концентрации глюкозы и фруктозы 1 г материала клубней (включая мякоть и кожуру) измельчали в жидком азоте, суспендировали в 10 мл 80 \% этанола и центрифугировали при 16000 g в течение 15 мин. Супернатант анализировали с помощью высокоэффективной жидкостной хроматографии (ВЭЖХ) с использованием хроматографа Varian ProStar («Varian Inc.», США), дифференциального рефрактометрического детектора $102 \mathrm{M}$ для хроматографа (модель Стайер, ЗАО СКБ «ХРОМАТЭК», Россия) и ко-

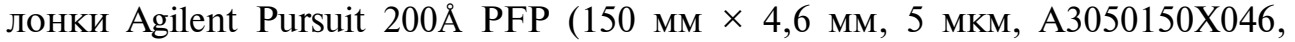
«Agilent», США). Изократическое элюирование выполняли с использованием смеси ацетонитрил:вода (75:25 v/v) в качестве подвижной фазы; скорость потока $-1,5$ мл/мин, температура $-30{ }^{\circ} \mathrm{C}$. Биохимический анализ проводили в двух биологических и трех технических повторах.

Для статистической обработки результатов РВ-ПЦР и анализа содержания крахмала и редуцирующих сахаров применяли программу GraphPad Prism v.8 («GraphPad Software Inc.», США; https://www.graphpad.com/scientificsoftware/prism/). Данные выражали как среднее значение $(M)$ со стандартным отклонением $( \pm \mathrm{SE})$ на основе двух биологических и трех технических повторов для каждого варианта кДНК и каждого образца картофеля. Для оценки различий в экспрессии генов и содержании углеводов использовали $t$-критерий Уэлча (unequal variance, Welch's $t$-test) (p $<0,05$ указывает на статистическую значимость различий).

Результаты. Первым этапом работы стал биоинформатический анализ имеющихся в базе данных NCBI сведений об амилазе StAmy23 картофеля. Последовательности гена, мРНK и белка StAmy23 картофеля (2871 н.; 4 экзона; LOC102598863 alpha-amylase-like [Solanum tuberosum (potato)]; Gene ID: 102598863, хромосома VI) были извлечены из GenBank NCBI (https://www.ncbi.nlm.nih.gov/).

Анализ с помощью NCBI-BLASTP (в базе NCBI Non-redundant 
protein sequences) показал, что самыми близкими гомологами амилазы StAmy23 (Protein ID: XP_006354888.1) являются белки $\alpha$-амилаз разных copтов картофеля (например, XP_004238157.1, идентичность 98 \%) и томата Solanum lycopersicum L. (например, XP_004235226.1, 91 \%) (рис. 1, А). С гомологичной $\alpha$-амилазой более отдаленного вида пасленовых Capsicum annиит L. (РНT84617.1) идентичность аминокислотной последовательности StAmy23 картофеля составила $91 \%$. Филогенетический анализ на основе аминокислотной последовательности StAmy23 и гомологов амилазы подтвердил выявленное сходство (см. рис. 1, Б).

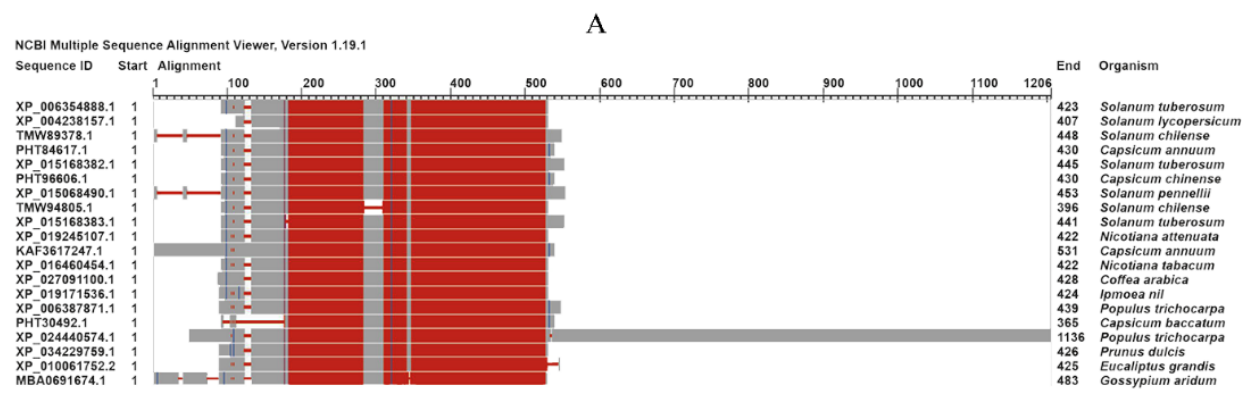

Б

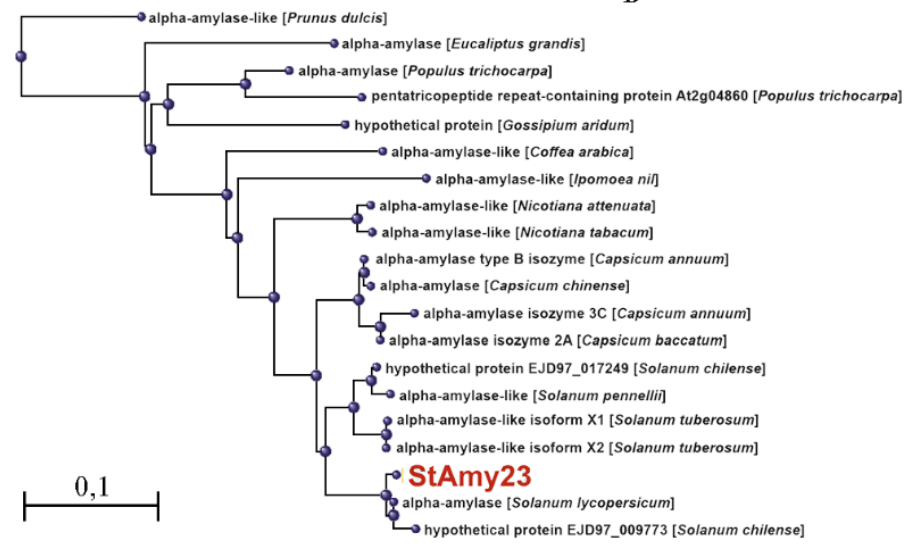

Рис. 1. Структурно-филогенетический анализ $\alpha$-амилазы картофеля (Solanum tuberosum L.) StAmy23: А - степень консерватизма аминокислотной последовательности между видами (высококонсервативные последовательности выделены красным, менее консервативные голубым, вариабельные участки - серым, делеции вариабельных участков - белым с узкой красной полосой), Б - дендрограмма эволюционных связей StAmy23 картофеля с ближайшими известными белками-гомологами (номера доступа в NCBI указаны слева на схеме выравнивания аминокислотных последовательностей). Структурное сравнение выполнено на основе данных проведенного поиска ближайших гомологов StAmy23 (Gene ID: 102598863) в базе данных NCBI с помощью программы BLASTP (https://blast.ncbi.nlm.nih.gov/Blast.cgi). Филогенетическая дендрограмма построена как результат анализа и визуализации BLASTPданных структурного сравнения гомологов StAmy23 методом Fast Minimum Evolution (Grishin distance matrix, https://www.ncbi.nlm.nih.gov/blast/treeview/).

На основе выполненного сравнительного структурного анализа найденных в NCBI последовательностей генов и мРНК $\alpha$-амилаз, гомологичных StAmy23 у видов Solanum, нами были разработаны кДНК-специфичные праймеры для проведения PB-ПЦР: StAmy23-F - 5'-ATGGCGCTTGATGAAAGTCAGC-3' и StAmy23-R - 5' -CCAGACTTTGCAATATCAGGAAC-3'.

Вторым этапом работы стал анализ профиля экспрессии гена StAmy23 в различных тканях растений картофеля в сопоставлении с содержанием крахмала и редуцирующих сахаров (глюкоза и фруктоза) в клубнях 
тех же растений с целью поиска возможной зависимости между этими характеристиками.

Для работы были выбраны три сорта картофеля - Saturna, Gala и Барин с разным содержанием крахмала в клубнях (https://reestr.gossortrf.ru/). Образцы сортов выращивали в полевых условиях, и свежесобранные клубни (включая и мякоть, и кожуру) использовали для определения содержания крахмала и редуцирующих сахаров (табл.). Биохимический анализ показал, что самым высоким и сходным было содержание крахмала в клубнях у сортов Gala и Saturna, тогда как у сорта Барин оно оказалось почти в 2 раза ниже (см. табл.). Полученные результаты отличались от данных оригинаторов сортов, согласно которым клубни сорта Gala характеризуются наименьшим содержанием крахмала в сравнении с сортами Saturna и Барин, а клубни сорта Барин занимают среднее положение между сортами Gala и Saturna (см. табл.). Подобные различия могут быть следствием влияния погодных условий при выращивании анализируемых в нашей работе образцов. Наибольшее количество редуцирующих сахаров обнаружили в клубнях сорта Saturna, наименьшее - у сорта Gala, что совпало соответственно с наибольшим и наименьшим содержанием крахмала среди образцов. При этом клубни сорта Gala содержали соответственно в 4,5 и в 24,5 раза меньше глюкозы и фруктозы, чем клубни сортов Барин и Saturna (см. табл.).

Содержание крахмала и редуцирующих сахаров в свежесобранных клубнях у исследуемых сортов картофеля (Solanum tuberosum L.) (M士SE)

\begin{tabular}{l|c|c|c}
\hline \multicolumn{1}{c|}{ Сорт } & $\begin{array}{l}\text { Крахмал (согласно официаль- } \\
\text { ным характеристикам сорта), } \%\end{array}$ & $\begin{array}{c}\text { Крахмал, } \\
\text { мг/г ткани }\end{array}$ & $\begin{array}{l}\text { Редуцирующие сахара } \\
\text { (глюкоза/фруктоза), мг/г ткани }\end{array}$ \\
\hline Saturna & $16,5-21,4$ & $1111,34 \pm 0,23$ & $0,217 \pm 0,021 / 0,175 \pm 0,070$ \\
Барин & $13,4-14,6$ & $6,3 \pm 0,05$ & $0,056 \pm 0,007 / 0,016 \pm 0,009$ \\
Gala & $10,2-13,2$ & $1111,34 \pm 0,34$ & $0,016 \pm 0,001 / 0,000$ \\
\hline
\end{tabular}

У тех же образцов мы исследовали транскрипционную активность гена StAmy23 с использованием разработанных нами праймеров StAmy23F/StAmy23-R. Ранее J. Ноu с соавт. (4) и H. Zhang с соавт. (20) изучили экспрессию StAmy23 в листьях, стеблях и клубнях устойчивых и чувствительных к холодовому осахариванию сортов картофеля и показали ее присутствие во всех трех видах тканей. При этом уровень экспрессии гена в свежесобранных клубнях не различался между сортами, тогда как в листьях мРНК StAmy23 активнее транскрибировалась у устойчивого сорта (20). Оценку экспрессии этого гена в других частях растения не проводили. Поэтому представляло интерес оценить профиль транскрипции StAmy23 в шести различных органах растений картофеля - в листьях, стеблях, ягодах, корнях, столонах и клубнях (отдельно мякоть и кожура). Кроме того, сравнение экспрессии гена у трех сортов с разным содержанием крахмала и редуцирующих сахаров в клубнях (см. табл.) могло бы выявить возможную связь между уровнем транскрипции StAmy23 и накоплением углеводов на момент сбора урожая картофеля.

Результаты РВ-ПЦР показали, что по сравнению с листьями в мякоти клубней у сортов Saturna и Gala уровень транскрипции гена StAmy23 повышен, в то время как у сорта Барин - понижен (рис. 2). В совокупности с данными Н. Zhang с соавт. (20), согласно которым в период сбора урожая уровень экспрессии гена в клубнях либо ниже, либо такой же, как в листьях, можно предположить, что для каждого сорта картофеля характерен свой профиль транскрипции StAmy23. Наличие мРНК StAmy23 во всех анализируемых тканях и неожиданно высокая в сравнении с клубнями экспрессия гена в вегетативных органах и ягодах предполагают отсутствие 
выраженной специфичности работы фермента StAmy23 в отношении определенных тканей растения. Уровень транскрипции StAmy23 в нефотосинтезирующих корнях и столонах либо соответствовал (сорт Saturna), либо значительно (в 1,8-8,0 раз) превышал (сорта Барин, Gala) таковой в клубнях. Высокую экспрессию наблюдали и в фотосинтезирующих стеблях и ягодах, хотя в листьях ее уровень был сравнительно низким (см. рис. 2).

При сравнении уровней экспрессии StAmy23 между сортами с разным содержанием крахмала и сахаров оказалось, что в стеблях самую высокую транскрипционную активность StAmy23 имел сорт Gala, тогда как самую низкую - сорт Saturna (см. рис. 2). У изученных сортов листья характеризовались сходным уровнем экспрессии с небольшим преимуществом сорта Барин. В ягодах экспрессия StAmy23 была наибольшей у сорта Барин, в корнях - у сорта Gala, а в столонах - у сортов Барин и Gala. B запасающих органах - клубнях уровень экспрессии StAmy23 был самым высоким у сорта Gala, самым низким у сорта Барин. При этом по транскрипционной активности гена StAmy23 в кожуре клубней изученные сорта не различались (см. рис. 2).

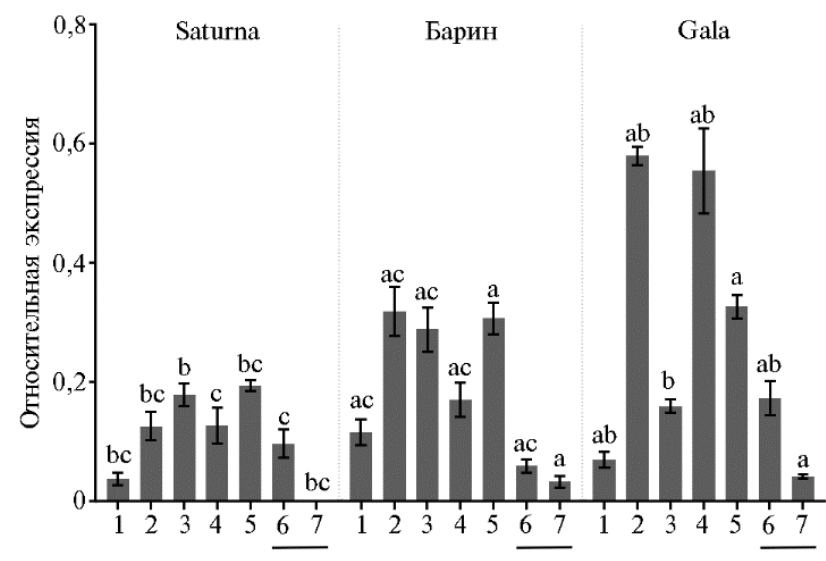

Рис. 2. Профиль экспрессии гена StAmy23 в листьях (1), стеблях (2), ягодах (3), корнях (4), столонах (5) и клубнях (подчеркнуто) - в мякоти (6) и кожуре (7) у картофеля (Solanum tuberosum L.) сортов Saturna (a), Барин (b) и Gala (c). Референсные гены ef1 и sec3. Анализ проведен в двух биологических и трех технических повторах, приведены значения $M \pm \mathrm{SE}$. Буквами a, b и с над столбцами обозначены статистически значимые различия в уровне экспрессии гена между сортами $(\mathrm{p}<0,05)$. Например, bс означает, что уровень экспрессии гена в отмеченной ткани у сорта Saturna (a) достоверно отличается от такового у сортов Барин (b) и Gala (c).

Сопоставив данные по транскрипционной активности (см. рис. 2) и результаты биохимического анализа (см. табл.), можно предположить наличие положительной зависимости между уровнем транскрипции StAmy23 и содержанием крахмала, но не содержанием редуцирующих сахаров в клубнях. Так, уровень экспрессии StAmy23 самый высокий у сорта Gala и средний - у сорта Saturna, при этом содержание крахмала у этих сортов одинаково выше, чем у сорта Барин с наименьшим уровнем экспрессии гена (см. табл., рис. 2). В то же время самое высокое количество глюкозы и фруктозы обнаружено у сорта Saturna со средним уровнем экспрессии гена, а самое низкое - у сорта Gala с наивысшим уровнем экспрессии StAmy23 (см. табл., рис. 2).

Однако на основании анализа всего трех сортов рано делать предположения о наличии зависимости между транскрипционной активностью StAmy23 и содержанием углеводов в клубнях. Для строгих выводов понадобится изучение выборки образцов картофеля, контрастных по содержанию крахмала и сахаров в клубнях.

Также нужно учитывать, что активность $\alpha$-амилазы StAmy23 дополняется действием $\beta$-амилаз и крахмалфосфорилаз и может подавляться ингибиторами амилаз $(24,25)$. И поэтому правильнее всего было бы искать корреляции между совокупным профилем экспрессии генов, кодирующих 
упомянутые ферменты, и содержанием крахмала.

K примеру, ингибитор амилаз SbAI на посттрансляционном уровне регулирует активность амилаз $(26,27)$. Между экспрессией гена $S b A I$ и содержанием редуцирующих сахаров в клубнях показана обратная зависимость (28). Ранее было выявлено, что в клубнях картофеля сорта Барин уровень экспрессии $S b A I$ значительно (примерно в 3 раза) ниже, чем у сорта Северное сияние, пригодного для производства хрустящего картофеля (25). Исходя из этих данных, непригодность клубней для жарки у всех трех сортов, изученных нами в настоящей работе, может быть связана с низким уровнем транскрипции $S b A I$ и, как следствие, с чувствительностью к холодовому осахариванию.

Кроме того, если говорить о корреляциях с содержанием глюкозы и фруктозы, то следует учитывать и активность генов ферментов гидролиза сахарозы (инвертазы, сахарозосинтазы) и ингибиторов инвертаз (29-31). Также нужно принимать во внимание процессы утилизации глюкозы в клетках растений, в том числе на синтез крахмала и сахарозы. Необходимо помнить и о том, что источником глюкозы в клубнях может быть не только мальтоза, образующаяся в результате расщепления амилазами крахмала (32), но и сахароза, которая производится в фотосинтетически активных листьях и перемещается из них в клубни (33).

Путь разложения крахмала в запасающих органах отличается от пути разложения крахмала в листьях (7), однако в обоих случаях в процесс вовлечены амилазы. Известно, что листья двудольных (включая картофель) богаты крахмалом, тогда как листья зерновых (например, ячмень) - сахарами $(24,34)$. Это предполагает, что основная роль транзиентного крахмала в листьях картофеля состоит в основном в поддержании процессов роста в ночное время, как это было показано для Arabidopsis thaliana (35-37). Наличие транскрипции гена StAmy23 в фотосинтезирующих тканях растений картофеля свидетельствует о том, что кодируемый фермент участвует в регуляции метаболизма крахмала не только в запасающих органах (ягодах и клубнях), но и в вегетативных тканях для поддержания процессов роста растения и ответа на абиотические стрессы.

Итак, в настоящей работе проведен биоинформатический структурно-филогенетический анализ $\alpha$-амилазы StAmy23, который определил ближайших гомологов фермента. Ими являются $\alpha$-амилазы представителей семейства Solanaceae, прежде всего видов и сортов картофеля, томата и перца. Биохимический анализ свежесобранных клубней трех сортов картофеля (Барин, Saturna и Gala) обнаружил различия между сортами в содержании как крахмала, так и редуцирующих сахаров. Так, у сорта Барин содержание крахмала (6,3 мг/г ткани) было в 2 раза ниже, чем у сортов Gala и Saturna, имеющих сходные высокие показатели (около 11,34 мг/г ткани). Количество редуцирующих сахаров (глюкозы/фруктозы) оказалось наименьшим в клубнях сорта Gala; клубни сортов Барин и Saturna содержали соответственно в 4,5 и в 24,5 раза больше глюкозы/фруктозы $(0,056 / 0,016$ и 0,217/0,175 против 0,016/0,000 мг/г ткани у сорта Gala). Нами определен профиль экспрессии гена StAmy23 в стеблях и листьях анализируемых сортов, а также впервые - в других органах и тканях растения картофеля (корни, столоны, ягоды; в клубнях - отдельно в кожуре и мякоти). Показано, что уровень транскрипции StAmy23 в корнях и столонах либо соответствует (у сорта Saturna), либо превышает (сорта Барин и Gala) таковой в клубнях. Самый высокий уровень экспрессии гена StAmy23 в ягодах выявлен у сорта Барин $(0,29)$, в корнях и клубнях у сорта Gala $(0,55$ и 0,17$)$ и в столонах у сортов Барин и Gala $(0,31$ и 0,33$)$. Предполагается наличие 
положительной зависимости между уровнем транскрипции StAmy23 и содержанием крахмала (но не редуцирующих сахаров) в клубнях. Транскрипционная активность гена StAmy 23 во всех проанализированных тканях растения картофеля указывает на возможное участие $\alpha$-амилазы StAmy23 в гидролизе крахмала не только в запасающих, но и в вегетативных (включая фотосинтезирующие) органах для поддержания физиологических процессов роста и ответа растений на стресс. Полученные данные перспективны для расширения понимания фундаментальных процессов, лежащих в основе углеводного метаболизма растительной клетки, в том числе его изменений в ответ на стрессы. С практической точки зрения результаты исследования могут быть использованы в селекции сортов картофеля для отбора доноров хозяйственно ценных признаков (к примеру, устойчивости к холодовому осахариванию клубней, резистентности к пониженным температурам культивирования, высокой или низкой крахмалистости клубней). Продолжение исследований будет связано с изучением совокупного влияния $\alpha$ - и $\beta$-амилаз на различные характеристики растений разных сортов и видов картофеля.

\footnotetext{
${ }^{1}$ Институт биоинженерии,

ФИЦ Фундаментальные основы биотехнологии РАН,

119071 Россия, г. Москва, Ленинский просп., 33, корп. 2,

e-mail: kulakova97@mail.ru $\bowtie$, shchennikova@yandex.ru,

ekochieva@yandex.ru;

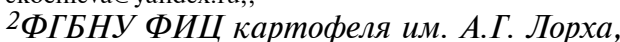

140051 Россия, Московская обл., Люберецкий р-н, п. Красково,

ул. Лорха, 23, литера «В»,

e-mail: a-mela@mail.ru
}

Sel'skokhozyaistvennaya biologiya [Agricultural Biology], 2021, V. 56, № 5, pp. 899-909

\title{
EXPRESSION OF THE $\alpha$-AMYLASE GENE StAmy 23 IN PHOTOSYNTHETIC AND NON-PHOTOSYNTHETIC TISSUES OF POTATO (Solanum tuberosum L.) CULTIVARS
}

\author{
A.V. Kulakova ${ }^{1}$, A.A. Meleshin $^{2}$, A.V. Shchennikova ${ }^{1}$, E.Z. Kochieva ${ }^{1}$
}

${ }^{1}$ Institute of Bioengineering, Federal Research Center Fundamentals of Biotechnology RAS, 33/2, Leninskii prospect, Moscow, 119071 Russia, e-mail kulakova_97@mail.ru ( $₫$ corresponding author), shchennikova@yandex.ru, ekochieva@yandex.ru;

${ }^{2}$ Lorkha Russian Potato Research Centre, 23-B, ul. Lorkha, pos. Korenevo, Lyuberetsky District, Moscow Province, 140051 Russia, e-mail a-mela@mail.ru

ORCID:

Kulakova A.V. orcid.org/0000-0002-3124-525X

Meleshin A.A. orcid.org/0000-0002-6018-3676

Shchennikova A.V. orcid.org/0000-0003-4692-3727

The authors declare no conflict of interests

Kochieva E.Z. orcid.org/0000-0002-6091-0765

Acknowledgments:

Supported financially from the Federal Program for the Development of Agriculture of the Russian Federation for 2017-2025 (subprogram "Development of potato breeding and seed production in the Russian Federation").

Received June 26, 2021 doi: 10.15389/agrobiology.2021.5.899eng

\section{Abstract}

Potato (Solanum tuberosum L.) is the fourth most important agricultural crop after cereals. Almost every tissue of a potato plant contains starch, the regulation of metabolism and the physiological role of which depends on the type of tissue, the stage of plant development and external factors. Starch hydrolysis is catalyzed by $\alpha-(\mathrm{AMY})$ and $\beta-$ (BAM) amylases. By degradation of cytosolic phytoglycogen, StAmy23 amylase regulates tuber cold-induced sweetening and physiological dormancy. Few available studies on StAmy 23 have focused on gene activity in potato tubers, including in response to cold stress. In this study, StAmy 23 expression pattern in photosynthetic and non-photosynthetic tissues of potato plants of three cultivars, differing in starch content in tubers, was determined for the first time. Structural and phylogenetic analyses revealed that the closest homologs of StAmy23 are the $\alpha-$ amylases of various potato and tomato cultivars. Analysis of the carbohydrate content in freshly harvested tubers of the studied potato cultivars showed a similar high starch content for cv. Gala and cv. Saturna and almost 2 times lower for cv. Barin (6.3 vs. $11.34 \mathrm{mg} / \mathrm{g}$ of tissue). The largest amount of reducing sugars was found in tubers of cv. Saturna; cv. Gala tubers contained 4.5 and 24.5 times less of glucose/fructose than cv. Barin and cv. Saturna tubers, respectively (0.016/0.000 vs. 0.056/0.016 
and $0.217 / 0.175 \mathrm{mg} / \mathrm{g}$ of tissue). For the first time, the expression profile of StAmy 23 was determined not only in tubers, leaves and stems, but also in other organs and tissues of the potato plant. A high level of gene expression in stems and fruits was shown. In non-photosynthetic roots and stolons, StAmy23 transcription level either corresponded (cv. Saturna) or significantly exceeded (cv. Barin, cv. Gala) that in tubers. In stems, the highest and lowest StAmy 23 transcription levels were observed in cv. Gala and cv. Saturna, respectively (0.58 and 0.13). Leaves and tuber peels showed similar, relatively low levels of StAmy23 expression. In fruits, the highest StAmy23 expression was found in cv. Barin (0.29), in the roots and tubers - in cv. Gala (0.55 and 0.17), and in the stolons - in cv. Barin and cv. Gala (0.31 and 0.33 ). A positive association was proposed between the level of StAmy 23 transcription and the starch content (but not the content of reducing sugars) in tubers. The transcriptional activity of the StAmy23 gene in photosynthetic tissues of potato plants suggests the participation of encoded $\alpha$-amylase in starch hydrolysis not only in storage organs, but also in vegetative organs to maintain physiological growth processes and plant stress response.

Keywords: Solanum tuberosum, potato, $\alpha$-amylase StAmy23, starch content, reducing sugars, gene expression.

\section{REFERENCES}

1. Sonnewald S., Sonnewald U. Regulation of potato tuber sprouting. Planta, 2014, 239(1): 27-38 (doi: 10.1007/s00425-013-1968-z).

2. Hou J., Liu T., Reid S., Zhang H., Peng X., Sun K., Du J., Sonnewald U., Song B. Silencing of $\alpha$-amylase StAmy23 in potato tuber leads to delayed sprouting. Plant Physiology and Biochemistry, 2019, 139: 411-418 (doi: 10.1016/j.plaphy.2019.03.044).

3. Shepherd L.V.T., Bradshaw J.E., Dale M.F.B., McNicol J.W., Pont S.D.A., Mottram D.S., Davies H.V. Variation in acrylamide producing potential in potato: segregation of the trait in a breeding population. Food Chemistry, 2010, 123(3): 568-573 (doi: 10.1016/j.foodchem.2010.04.070).

4. Hou J., Zhang H., Liu J., Reid S., Liu T., Xu S., Tian Z., Sonnewald U., Song B., Xie C. Amylases StAmy23, StBAM1 and StBAM9 regulate cold-induced sweetening of potato tubers in distinct ways. Journal of Experimental Botany, 2017, 68(9): 2317-2331 (doi: 10.1093/jxb/erx076).

5. Hedhly A., Vogler H., Schmid M.W., Pazmino D., Gagliardini V., Santelia D., Grossniklaus U. Starch turnover and metabolism during flower and early embryo development. Plant Physiology, 2016, 172 (4): 2388-2402 (doi: 10.1104/pp.16.00916).

6. Tang L.Y., Nagata N., Matsushima R., Chen Y.L., Yoshioka Y., Sakamoto W. Visualization of Plastids in pollen grains: involvement of FtsZ1in pollen plastid division. Plant Cell Physiology, 2009, 50(4): 904-908 (doi: 10.1093/pcp/pcp042).

7. Dong S., Beckles D.M. Dynamic changes in the starch-sugar interconversion within plant source and sink tissues promote a better abiotic stress response. Journal of Plant Physiology, 2019, 234235: 80-93 (doi: 10.1016/j.jplph.2019.01.007).

8. Zeeman S.C., Tiessen A., Pilling E., Kato K.L., Donald A.M., Smith A.M. Starch synthesis in arabidopsis. Granule synthesis, composition, and structure. Plant Physiology, 2002, 129(2): 516529 (doi: 10.1104/pp.003756).

9. Zeeman S.C., Smith M.C., Smith A.M. The diurnal metabolism of leaf starch. The Biochemical Journal, 2007, 401(1): 13-28 (doi: 10.1042/BJ20061393).

10. Benkeblia N., Alexopoulos A.A., Passam H.C. Physiology and biochemistry regulation of dormancy and sprouting in potato tuber (Solanum tuberosum L.). Fruit, Vegetable and Cereal Science and Biotechnology, 2008, 2: 54-68.

11. Thalmann M., Santelia D. Starch as a determinant of plant fitness under abiotic stress. The New Phytologist, 2017, 214(3): 943-951 (doi: 10.1111/nph.14491).

12. MacNeill G.J., Mehrpouyan S., Minow M.A., Patterson J.A., Tetlow I.J., Emes M.J. Starch as a source, starch as a sink: the bifunctional role of starch in carbon allocation. Journal of Experimental Botany, 2017, 68(16): 4433-4453 (doi: 10.1093/jxb/erx291).

13. Preiss J. Regulation of the biosynthesis and degradation of starch. Annual Reviews of Plant Physiology, 1982, 33: 431-454.

14. Solomos T., Mattoo A.K. Starch-sugar metabolism in potato (Solanum tuberosum) tubers in response to temperature variations. In: Genetic improvement of Solanaceous crops. Vol. I. M.K. Razdan, A.K. Mattoo (eds.). Science Publishers, Enfield, NH, United States, 2005: 209-234.

15. Asatsuma S., Sawada C., Itoh K., Okito M., Kitajima A., Mitsui T. Involvement of $\alpha$-amylase I1 in starch degradation in rice chloroplasts. Plant \& Cell Physiology, 2005, 46(6): 858-869 (doi: 10.1093/pcp/pci091).

16. Kitajima A., Asatsuma S., Okada H., Hamada Y., Kaneko K., Nanjo Y., Kawagoe Y., Toyooka K., Matsuoka K., Takeuchi M., Nakano A., Mitsui T. The rice $\alpha$-amylase glycoprotein is targeted from the Golgi apparatus through the secretory pathway to the plastids. The Plant Cell, 2009, 21(9): 2844-2858 (doi: 10.1105/tpc.109.068288).

17. Yu T.S., Zeeman S.C., Thorneycroft D., Fulton D.C., Dunstan H., Lue W-L., Hegemann B., Tung S-Y., Umemoto T., Chapple A., Tsai D-L., Wang S-M., Smith A.M., Chen J., Smith S.M. 
$\alpha$-Amylase is not required for breakdown of transitory starch in Arabidopsis leaves. The Journal of Biological Chemistry, 2005, 280(11): 9773-9779 (doi: 10.1074/jbc.m413638200).

18. Glaring M.A., Baumann M.J., Abou H.M, Nakai N., Nakai H., Santelia D., Sigurskjold B.W., Zeeman S.C., Blennow A., Svensson B. Starchbinding domains in the CBM45 family - lowaffinity domains from glucan, water dikinase and $\alpha$-amylase involved in plastidial starch metabolism. The FEBS Journal, 2011, 278(7): 1175-1185 (doi: 10.1111/j.1742-4658.2011.08043.x).

19. Van Harsselaar J.K., Lorenz J., Senning M., Sonnewald U., Sonnewald S. Genome-wide analysis of starch metabolism genes in potato (Solanum tuberosum L.). BMC Genomics, 2017, 18(1): 37 (doi: 10.1186/s12864-016-3381-z).

20. Zhang H., Hou J., Liu J., Xie C., Song B. Amylase analysis in potato starch degradation during cold storage and sprouting. Potato Research, 2014, 57: 47-58 (doi: 10.1007/s11540-014-9252-6).

21. Wegrzyn T., Reilly K., Cipriani G., Murphy P., Newcomb R., Gardner R., MacRae E. A novel $\alpha$-amylase gene is transiently upregulated during low temperature exposure in apple fruit. European Journal of Biochemistry, 2000, 267(5): 1313-1322 (doi: 10.1046/j.1432-1327.2000.01087.x).

22. Lopez-Pardo R., de Galarreta J.I.R., Ritter E. Selection of housekeeping genes for qRT-PCR analysis in potato tubers under cold stress. Molecular Breeding, 2013, 31(1): 39-45 (doi: 10.1007/s11032-012-9766-z).

23. Tang X., Zhang N., Si H., Calderón-Urrea A. Selection and validation of reference genes for RTqPCR analysis in potato under abiotic stress. Plant Methods, 2017, 13: 85 (doi: 10.1186/s13007017-0238-7).

24. Slugina M.A., Shchennikova A.V., Kochieva E.Z. The expression pattern of the Phola genes encoding plastidic starch phosphorylase correlates with the degradation of starch during fruit ripening in green-fruited and red-fruited tomato species. Functional Plant Biology, 2019, 46(12): 1146-1157 (doi: 10.1071/FP18317).

25. Slugina M.A., Filyushin M.A., Meleshin A.A., Shchennikova A.V., Kochieva E.Z. Genetika, 2020, 56(3): 361-365 (doi: 10.31857/S0016675820030169) (in Russ.).

26. Liu X., Cheng S., Liu J., Oua Y., Song B., Zhang C., Lin Y., Li X.-Q., Xie C. The potato protease inhibitor gene, St-Inh, plays roles in the cold-induced sweetening of potato tubers by modulating invertase activity. Postharvest Biology and Technology, 2013, 86: 265-271 (doi: 10.1016/j.postharvbio.2013.07.001).

27. Mckenzie M.J., Chen R.K., Harris J.C., Ashworth M.J., Brummell D.A. Post-translational regulation of acid invertase activity by vacuolar invertase inhibitor affects resistance to cold-induced sweetening of potato tubers. Plant, Cell \& Environment, 2013, 36(1): 176-185 (doi: 10.1111/j.13653040.2012.02565.x).

28. Zhang H., Liu J., Hou J., Yao Y., Lin Y., Ou Y., Song B., Xie C. The potato amylase inhibitor gene SbAI regulates cold-induced sweetening in potato tubers by modulating amylase activity. Plant Biotechnology Journal, 2014, 12(7): 984-993 (doi: 10.1111/pbi.12221).

29. Slugina M.A., Shchennikova A.V., Kochieva E.Z. TAI vacuolar invertase orthologs: the interspecific variability in tomato plants (Solanum section Lycopersicon). Molecular Genetics and Genomics, 2017, 292(5): 1123-1138 (doi: 10.1007/s00438-017-1336-y).

30. Peyrot des Gachons C., Breslin P.A. Salivary amylase: digestion and metabolic syndrome. Current Diabetes Reports, 2016, 16(10): 102 (doi: 10.1007/s11892-016-0794-7).

31. Braun D.M., Wang L., Ruan Y.L. Understanding and manipulating sucrose phloem loading, unloading, metabolism, and signalling to enhance crop yield and food security. Journal of Experimental Botany, 2014, 65(7): 1713-1735 (doi: 10.1093/jxb/ert416).

32. Slugina M.A., Shchennikova A.V., Meleshin A.A., Kochieva E.Z. Homologs of vacuolar invertase inhibitor INH2 in tuber-bearing wild potato species and Solanum tuberosum: gene polymorphism and co-expression with saccharolytic enzyme genes in response to cold stress. Scientia Horticulturae, 2020, 269: 109425 (doi: 10.1016/j.scienta.2020.109425).

33. Slugina M.A., Shchennikova A.V., Kochieva, E.Z. Differences in the sucrose synthase gene SUS1 expression pattern between Solanum lycopersicum and wild tomato species. Theoretical and Experimental Plant Physiology, 2019, 31: 455-462 (doi: 10.1007/s40626-019-00158-6).

34. Cook F.R., Fahy B., Trafford K. A rice mutant lacking a large subunit of ADP-glucose pyrophosphorylase has drastically reduced starch content in the culm but normal plant morphology and yield. Functional Plant Biology, 2012, 39(12): 1068-1078 (doi: 10.1071/FP12186).

35. Okamura M., Hirose T., Hashida Y., Ohsugi R., Aoki N. Suppression of starch synthesis in rice stems splays tiller angle due to gravitropic insensitivity but does not affect yield. Functional Plant Biology, 2015, 42(1): 31-41 (doi: 10.1071/FP14159).

36. Graf A., Smith A.M. Starch and the clock: the dark side of plant productivity. Trends in Plant Science, 2011, 16(3): 169-175 (doi: 10.1016/j.tplants.2010.12.003).

37. Sulpice R., Pyl E.T., Ishihara H., Trenkamp S., Steinfath M., Witucka-Wall H., Gibon Y., Usadel B., Poree F., Piques M.C., Von Korff M., Steinhauser M.C., Keurentjes J.J.B., Guenther M., Hoehne M., Selbig J., Fernie A.R., Altmann T., Stitt M. Starch as a major integrator in the regulation of plant growth. Proceedings of the National Academy of Sciences of the United States of America, 2009, 106(25): 10348-10353 (doi: 10.1073/pnas.0903478106). 